\title{
Handling Harassment By a Student
}

\author{
Paula Kilcoyne, Bentley College
}

Like many other institutions, the college at which I teach has been trying to address the problem of sexual harassment on campus. Among other things the administration has sponsored date rape lectures, hung posters saying "No means no," and published a pamphlet that defines harassment and gives students a list of people and offices to contact for help. Besides these general approaches, the college recently helped me deal with sexual harassment from a student in my American government class. The way it was handled not only helped me but also provided valuable lessons to the student and the entire class.

In order to keep track of class attendance (which I consider for final grades), I hand around a sign-up sheet every session. About a month after classes began, someone wrote a sexual remark on the sheet which was addressed directly to me. I was angry when I noticed it but, because I teach mostly freshmen, I thought it was due to immaturity. I suspected one student in particular but decided not to respond to the remark until the midterm exam when I could use its resultant handwriting sample to confront the student. I did, however, show the remark to my department chair.

In the next class the student wrote another comment. Although this was not sexual in nature, it again addressed me directly. When I told my department chair, he had me contact both a professor/lawyer, and the undergraduate dean's office for suggestions about how to handle the situation.

Since I wasn't sure who the culprit was, yet wanted the behavior to stop, both told me to make an announcement to the entire class about harassment. The dean said to invoke his office and tell students that he was taking the matter seriously. $\mathrm{He}$ also pointed out that this was highly unusual behavior and that the student, rather than being just immature, could have a larger problem. The dean thought that in the interest of the college community I should not only make a general announcement but also try to identify the culprit. At the very least he would then informally check to see if other complaints had been made about this student.

One of the dean's points in particular helped me to muster the courage to speak to my class: the behavior was unusual and could indicate a serious problem. I began my announcement by stating that I never thought I would ever be saying what I was about to say and that I felt embarrassed. I then told them about the remark, how disturbed I felt about it, and to whom I had spoken. While I talked, I know my voice cracked with emotion more than once. Even though the person I suspected had cut class that day, the remarks stopped nevertheless.

I had to wait until the midterm exam to confirm my suspicions about the identity of the student. I made a general announcement to the class, not identifying the student, but simply saying that I knew who it was and that he had 48 hours to see me or I would turn the matter over to the dean. I waited a week for him to come forward so we could deal with the situation privately. But the student chose to avoid me, leaving me no alternative but to follow through by sending his name to the dean.

When he finally saw the dean, the student was sent to face me and apologize. I think he assumed I was going to berate him, but instead I told him how the incident had made me feel. I said I was angry not only because he violated the boundaries of the student/professor relationship but because he also altered the relationship I had with a class I liked. I told him it was embarrassing to have so many of my colleagues know what he did. It was embarrassing to have to stand up in front of more than 30 students to discuss what had happened. In addition, I knew it was talked about all over the dorms, and my department chair was even asked about it at the gym.

The dean asked the student to think of a punishment. I suggested he write a 4-5 page paper on harassment because, being an educator, I wanted him to understand why what he did was wrong and what its implications could be in other settings. I made a list of questions for him to think about while he was reading three articles: one about the illegality of harassment, one that included actual testimony from women who have been harassed, and one of his choice. He would be allowed to select the specific articles. The student readily agreed to this assignment.

In retrospect, I think the way the incident was handled was constructive on several levels. First, it made the student directly accountable for his behavior, yet the punishment was a learning experience. I believe that young people in particular do not learn unless they see the consequences of their actions. Indeed, this student had not seemed very sorry after I spoke to the class the first time. He frequently came to class late, chatted with his friends, and giggled when we covered women's rights. After we talked, however, his behavior changed. His forcing me to hand the matter over to the dean was actually a help in this situation because the validity of my feelings and concerns was reinforced. The student could not assume that I was simply being overly sensitive.

Second, I still do not know if his behavior was symptomatic of a larger problem. If it is, the college will treat subsequent problems with greater seriousness. In addition, if he felt so free to harass a person in a position of authority, one can only speculate about whether later in life he might deal with co-workers, particularly subordinates, in such a manner. I can only hope that this experience may stop such inclinations.

Third, the incident was a lesson for the entire class (if not others through the gossip mill). They saw 
that even such "minor" incidents do not have to be tolerated by anyone. In addition, they saw that an individual who chooses to stand up and fight against such behavior is supported by the college, not brushed aside. I now make it a point to conclude my discussion of women's rights by saying that if any of them (even males) are harassed they should feel free to tell faculty or administra- tors because the situation will be taken seriously.

Finally, from a personal perspective, the support given to me made me able to take a step back from the anger and embarrassment. My initial inclination was to try to force the student to withdraw from my class. But now I see that some good has resulted from our discussion. Although institutions cannot keep inci- dents like this from happening, it is comforting to have them respond in such a positive manner.

\section{About the Author \\ Paula Kilcoyne is an assistant professor of government at Bentley College.}

\title{
The Status of Latinos in the Profession: Problems in Recruitment and Retention
}

\author{
Manuel Ávalos, Arizona State/West University
}

In 1970, an ad hoc committee of the American Political Science Association (APSA) published a report on Mexican Americans in the profession (Ad Hoc Committee on Mexican Americans in the Profession, 1970). The committee was concerned about the lack of scholarly work on America's second largest disadvantaged minority group. They were equally concerned about the lack of recruitment and training of Mexican American political scientists. In its report the committee noted that there were only two Mexican American scholars with doctoral degrees in political science in the entire nation and both had left academe for governmental service. The ad hoc committee concluded:

There is something basically wrong with political science when we (1) fail to adequately interpret the political presence of eight or more million people, and (2) when we fail to recruit and train more than a handful of their representatives. This, of course means a substantial loss of our body of knowledge and beyond this, it may represent a serious insensitivity, on our part, to the contemporary problem of mankind. (Ad Hoc Committee on Mexican Americans in the Profession, 1970: 352)

A subsequent study by the Committee on the Status of Chicanos of the Western Political Science Association (1975) of political science departments in institutions in thirteen western and southwestern states reported that the recruitment and retention of Chicanos, as well as course offerings in the area of Chicano politics in the discipline, had not improved.

The WPSA committee noted that while in general most schools perceived a need for more courses, students, and faculty in the area of Chicano politics, most of the schools offered very few suggestions for increasing the numbers of Chicanos in political science departments. The report concluded that most departments were neither interested in changing, nor willing to change their departmental policies for graduate admissions and faculty hiring which had led to the exclusion of Chicanos from the profession. The reason for this reluctance to change was a perceived threat to the academic standards of political science departments even though the exclusionary policies had never been tested with respect to their validity in predicting success or failure of Chicago graduate students or faculty (Committee on the Status of Chicanos, 1975).

While the number of Latino(a) Ph.D.'s has slowly increased since 1970, the WPSA Committee on the Status of Chicanos has identified only 56 Latino(a) Ph.D.'s in academic political science departments as of 1990 . The situation for Latino(a)s within the discipline has changed very little in the last twenty years and serious problems continue to exist. Two of the major problems which Latino(a)s face are in the areas of recruitment and retention (tenure and/or promotion).

\section{Recruitment and Retention of Latinos in Political Science}

Recruitment is a problem which begins at the undergraduate and graduate school level. In the last decade there has been a serious decline in the number of Latino(a)s entering and completing graduate programs in political science. Over the twenty year period between 1970 and 1980 nationwide Ph.D. granting political science programs have graduated a paltry average of less than 3 Latino(a)s per year. Of the fifty-six Latino's holding Ph.D.'s in 1990 (Committee on the Status of Chicanos, 1990) only thirteen (23 percent) have received a Ph.D. since 1980. And as of the fall of 1989 the

Of the fifty-six Latino's holding Ph.D.'s in 1990 only thirteen (23 percent) have received a Ph.D. since 1980.

Committee on the Status of Chicanos of the WPSA has been able to identify only 15 Latino(a) graduate students in Ph.D. programs across the United States. 